\title{
CORRELATION BETWEEN CLIMATIC FACTORS AND LEAFMINER (INSECTA: AGROMYZIDAE) INFESTATION ON THREE VEGETABLE CROPS IN CHITTAGONG, BANGLADESH
}

\author{
SANTOSH MAZUMDAR ${ }^{1}$ AND BADRUL AMIN BHUIYA \\ Department of Zoology, University of Chittagong, Chittagong-4331, Bangladesh
}

\begin{abstract}
Present study deals with the impact of climatic factors (temperature, humidity and wind speed) on agromyzid leafminers infestation in three cultivated crops viz. Tomato, French bean and Cowpea. Correlation studies showed that there was significantly positive relation of temperature, whereas wind speed showed negative relation to agromyzid infestation on cultivated crops. But there was no significant relation with humidity. Temperature influenced infestation rate as $18.70 \pm 4.12,16.01 \pm 15.85$ and $9.38 \pm 9.10$ $\%$ for Tomato, French bean and Cowpea respectively.
\end{abstract}

Key words: Leafminer, Agromyzids, Climatic factors, Crops, Bangladesh

\section{Introduction}

Agromyzid leafminers (Diptera: Agromyzidae) are a diverse group of pests whose larvae feed internally on leaves, stems, flowers, seeds and roots of a wide variety of plant hosts (Scheffer et al. 2007). They consist of more than 3000 species belonging to 30 genera worldwide (Shahreki et al. 2012). Climatic factors such as temperature, precipitation, humidity, wind speed and wind direction directly influence pest distribution and growth by affecting their rate of development, reproduction, migration and adaptation (Tshiala et al. 2012). Host plants of agromyzids are well documented for plants of economic importance (Spencer 1973 and 1990). In Bangladesh, more than 37 cultivated crops are affected by Agromyzid flies (Bhuiya et al. 2010).

Among the cultivated crops Tomato (Solanum lycopersicum L.) is a high valued nutritious vegetable, grown almost year round in Bangladesh. The total production of Tomato in Bangladesh was about 137,000 tons from 17, 900 hectares of land with an average yield of $7.65 \mathrm{t} /$ ha (BBS 2008). Though Tomato is a high valued nutritious and economic crop, its economic production is largely constrained by the attack of Agromyzid leafminers. The highest infestation was recorded in BARI Tomato-3 (82.54\%) (ARR 2009-2010). Other two crops namely French bean and Cowpea are leguminous crops which are cultivated as seasonal crops around the country. The present study aimed at evaluating the correlation of climatic factors with Agromyzid infestation on the aforesaid cultivated crops.

\footnotetext{
${ }^{1}$ Corresponding author: E-mail: mazumdarsantosh@gmail.com
} 


\section{Materials and Methods}

The experiments were carried out during the peak cultivation period December, 2011 to April 2012 in Chittagong University campus. Three crops, viz. BARI Tomato-3 ( $S$. lycopersicum L.), French bean (Phaseolus vulgaris L.) and Cowpea [Vigna sinensis (L.) Savi ex Hassle], were cultivated and managed. The field consisted of 6 plots each of 2.0 $\mathrm{m}^{2}$ areas. Due to variation in time period of life cycle, experimental crops were planted in different times. In the present study, first data were recorded when infestation of leafminers was noticed. The agromyzid leafminer infestation was calculated using following formula,

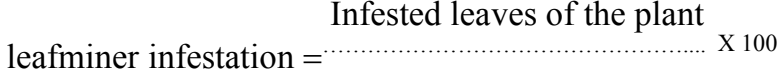

$$
\begin{aligned}
& \text { Total leaves of the plant }
\end{aligned}
$$

Agromyzid fly infested plant materials were collected from each plot as per schedule and brought to the Laboratory. Emerged flies were counted and recorded daily. Specimens were then dried and mounted on pin and card. Later they were imaged with a digital 3D imaging Microscope, Entovision. After that, these flies were identified and compared with reference collections housed in the Insect Museum of the, Department of Zoology, University of Chittagong. Finally, these reared agromyzid fly ID were confirmed as Liriomyza sativae Blanchard and Melanagromyza obtusa Malloch. The meteorological data were collected from Regional Agricultural Research Station (RARS), BARI, Hathazari, Chittagong, Bangladesh. The correlation between agromyzid infestation and climatic parameters was determined by Pearson's correlation method in SPSS software (SPSS, Inc. 2009). Data sheets were prepared by using MS Excel-2007.

\section{Results and Discussion}

It was observed that there is a correlation between climatic factors and agromyzid infestation. The infestation rate also varied with climatic factors, such as, $18.70 \pm 4.12$, $16.01 \pm 15.85$ and $9.38 \pm 9.10 \%$ for Tomato, French bean and Cowpea respectively as by influenced temperature (Table 1). From the recorded data, correlation studies showed

Table 1. Mean \pm SEM of Agromyzid infestation and Climatic factors of three different crops.

\begin{tabular}{lcccc}
\hline Crops & Infestation (\%) & $\begin{array}{c}\text { Humidity } \\
(\% \mathrm{RH})\end{array}$ & $\begin{array}{c}\text { Wind speed } \\
(\mathrm{Km} / \mathrm{H})\end{array}$ & Temperature $\left({ }^{\circ} \mathrm{C}\right)$ \\
\hline Tomato & $18.70 \pm 4.12$ & $62.38 \pm 19.91$ & $6.75 \pm 3.11$ & $22.88 \pm 4.12$ \\
French bean & $16.01 \pm 15.85$ & $62.38 \pm 19.91$ & $6.75 \pm 3.11$ & $22.88 \pm 4.12$ \\
Cowpea & $9.38 \pm 9.10$ & $62.38 \pm 19.91$ & $6.75 \pm 3.11$ & $22.88 \pm 4.12$ \\
\hline
\end{tabular}


that there was significantly positive relation with temperature, whereas wind speed showed negative relation with agromyzid infestation on cultivated crops. But there was no significant relation with humidity (Table 2). Among the experimented crops Tomato and Cowpea showed significant relation with temperature at the 0.01 level while French bean showed no significant relation in Table 2 . The rate of infestation exhibited an increasing trend with increasing temperature until the plants lost vigour or about to die (Fig. 1).

Table 2. Correlation among climatic factors of three cultivated crops.

\begin{tabular}{lccc}
\hline \multicolumn{1}{c}{ Crops } & \multicolumn{3}{c}{ Climatic parameters } \\
& Temperature $\left({ }^{\circ} \mathrm{C}\right)$ & Humidity $(\% \mathrm{RH})$ & Wind speed $(\mathrm{Km} / \mathrm{H})$ \\
\hline Tomato & $.884(* *)$ & -.221 & .242 \\
French bean & .274 & -.265 & -.191 \\
Cowpea & $.858(* *)$ & -.026 & .186 \\
\hline
\end{tabular}

** Correlation is significant at the 0.01 level (2-tailed).

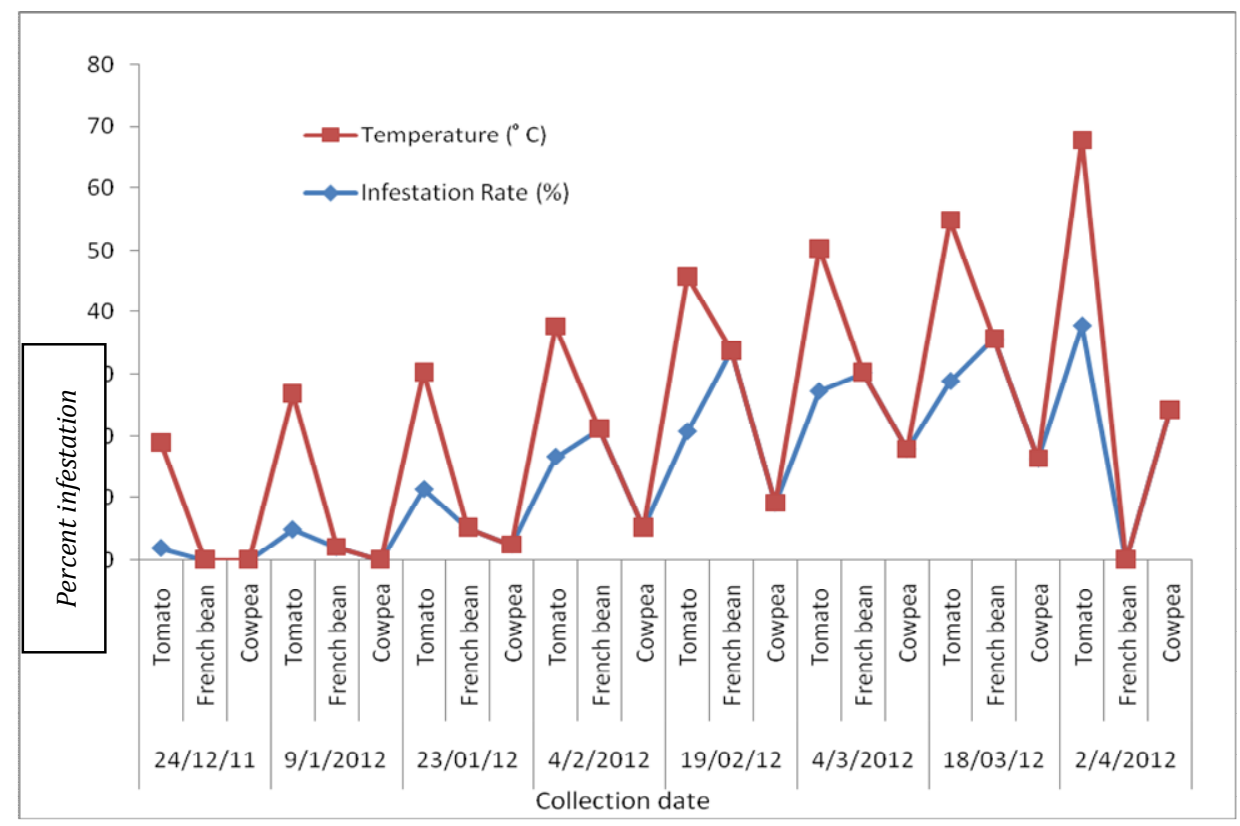

Fig. 1. Effect of temperature on agromyzid infestation rate among three cultivated crops. 
Atmospheric temperature, rainfall and relative humidity have regulatory effect on seasonal abundance and feeding potential of fern feeding insects (Patra and Bera 2007 and Kocmankova et al. 2008). The population of these flies was generally under control being influenced by certain climatic factors and due to the presence of natural enemies (IPE 1987 and Thapa 2011). Observations during the present study showed that natural infestation declined dramatically after maturation of host plants. This finding agrees with the observations made by Ganapathy et al. (2010) where they mentioned that the incidence of leaf miner L. trifolii (Burgess) in cowpea was least in November $(9.0 \%)$ and maximum in March (32.5\%) indicating that in the colder months the incidence was comparatively low (9.0 to $13.70 \%$ ). Present study also partly supports the results reported by Chaudhuri and Senapati (2004), where similar findings were recorded in colder months. According to Fagoonee (1984), Parrella (1984), Subharani and Singh (2007) and Yadav et al. (2011) abiotic factors like temperature, humidity and wind speed certainly influence the growth and the development of agromyzid leafminer agromyzid. Therefore it may be concluded that temperature, dampness and protection from wind are more favourable habitats for Agromyzid infestation.

\section{Acknowledgements}

The authors sincerely thank to Dr. Mostafa Kamal Pasha, Professor, Department of Botany, University of Chittagong, for identification of agricultural crops and Md. Zia Ur Rahman, Scientific Officer, Regional Agricultural Research Station, BARI, Hathazari, Chittagong for his kind assistance in experimental field preparation and Meteorological data collection. Authors are also thankful to Reaz Mohammad Mazumdar, Scientific Officer, BCSIR Laboratories, Chittagong for his suggestions on statistical analysis.

\section{References}

ARR (Annual Research Report). 2009-2010. Entomology Division, Bangladesh, Bangladesh Agricultural Research Institute (BARI), Gazipur, Joydevpur. pp. 395.

BBS (Bangladesh Bureau of Statistics). 2008. Statistical Year Book. Agricultural Statistics of Bangladesh. Bangladesh Bureau of Statistics, Statistics Division, Ministry of Planning. Govt. People's Repub. Bangladesh, Dhaka, pp. 137.

Bhuiya, B. A., S. Mazumdar, M. K. Pasha, W. Islam, M. I. Miah, and M. S. Hossain. 2010. A preliminary report on the agromyzid leaf miner pest attack on some agricultural crops and weeds in Bangladesh. J. Taxon. Biodiv. Res. 4: 47-50.

Chaudhuri, N. and S. K. Senapati. 2004. Incidence and biology of leaf miner, Liriomyza trifolii (Burg.) on tomato as influenced by weather conditions. Ann. Prot. Sci. 12: 55-58.

Fagoonee, I. 1984. Effect of azadirachtin and a neem extract on food utilization by Crocidolonia bionotalis. In: Proceedings of $2^{\text {nd }}$ International Neem Conference, Rauischholzhausen. pp. 221-224. 
Ganapathy, N., C. Durairaj and K. Aruppuchamy. 2010. Bio- ecology and management of serpentine leaf miner, Liriomyza trifolii (Burgess) in cowpea. Karnataka J. Agri. Sci. 23 (1): $159-160$.

IPE, M I. 1987. Biosystematic studies on Agromyzidae from India. Proc. Indian Acad. Sci. (Anim. Sci.) 96 (5): 573-581.

Kocmankova E., M. Trnka, Z. Žalud, D. Semeradova, M. Dubrovsky, F. Muška and M. Možny. 2008. The comparison of mapping methods of European corn borer (Ostrinia nubilalis) potential distribution. Plant Pro. Sci. 44: 49-56.

Parrella, M. P. 1984. Effect of teperature on oviposition, feeding, and longevity of Liriomyza trifolii (Dipterra: Agromyziidae). Can. Entomol. 116: 85-92.

Patra, B. and S. Bera. 2007. Herbivore damage to ferns caused by a Chrysomelid beetle from Lower Gangetic Plains of West Bengal, India. Amer Fern J. 97(1): 19-29.

Scheffer, S. J., I. S.Winkler and B. M. Wiegmann. 2007. Phylogenetic relationships within the leaf-mining flies (Diptera: Agromyzidae) inferred from sequence data from multiple genes. Mol. Phylogenet. Evol. 42: 756-775.

Shahreki, Z., E. Rakhshani and M. Sasakawa. 2012. A Contribution to the agromyzid leaf miners (Diptera: Agromyzidae) of Iran. Biologica nyssana. 3 (1): 31-36.

Spencer, K. A. 1973. Agromyzidae (Diptera) of economic importance. Dr. W. Junk B V. The Hague, Serie Entomologica. pp 418.

Spencer, K. A. 1990. Host specialization in the world Agromyzidae (Diptera). Series Entomologica 45. Kluwer Academic Publishers, Dordrecht. pp 444.

SPSS Inc. 2009. PASW statistics 18.0 command syntax reference. spss inc.

Subharani, S. and T. K. Singh. 2007. Influence of meteorological factors on population dynamics of pod fly, Melanagromyza obtusa Malloch (Diptera: Agromyzidae) in pigeonpea under agro-climatic conditions of Manipur. Indian J. Entomol. 69 (1): 78-80.

Thapa R. B. 2011. Description of new species of leaf miners (Diptera Agromyzidae) associated with leguminous host described from northern India. - Nepalese J. Biosci. 1: 66-82.

Tshiala, M. F., J. O. Botai and J. M. Olwoch. 2012. Leafminer agromyzid pest distribution over Limpopo province under changing climate. African J. Agri. Res. 7(48): 6515-6522.

Yadav, S. K., D. B. Ahuja, A. Dhandapani. 2011. Seasonal Activity of Pod Fly, Melanagromyza Obtusa (Malloch.) (Diptera: Agromyzidae) and Effect of Abiotic Factors on Its Incidence in Pigeon Pea. Indian J. Entomol. 73 (2): 162- 165. 